\title{
Dinamika Organisasi Muhammadiyah di Denpasar dalam Perspektif Sejarah 1998-2018
}

\author{
Widia Puspita Sari*, I Ketut Ardhana, I Wayan Tagel Eddy \\ Prodi Sejarah, Fakultas Ilmu Budaya, Universitas Udayana \\ Email: widiapuspitas123@gmail.com \\ *Corresponding Author
}

\begin{abstract}
This research discussed about the dynamics of Muhammadiyah Organization in Denpasar in the Hitorical Prespektive 1998-2018. The formulation of the problems are 1) How the activities of the Muhammadiyah Denpasar Area in religius Ideology 2) How are the views of the Muhammadiyah Denpasar Area towards members who are involved in politic 3) How are the the views of the citizens toward the Muhammadiyah Denpasar Area. In this research use historical methodology is oral history and political history. The analysis uses explanation theory, symbolic interactionalism and multicultural theory. The result is Muhammadiyah activities ini Denpasar in religion and politic. The final research find about Muhammadiyah in Denpasar recently not only enganged in religion but also partisipate in politic.
\end{abstract}

Keywords: Dynamics, Religion, and Muhammadiyah

\begin{abstract}
Abstrak
Penelitian ini membahas tentang Dinamika Organisasi Muhammadiyah di Denpasar Dalam Perspektif Sejarah 1998-2018. Adapun rumusan permasalahan dalam penelitian ini diantaranya adalah 1) Bagaimana aktivitas Muhammadiyah Daerah Denpasar dalam ideologi agama 2) Bagaimana pandangan Muhammadiyah Daerah Denpasar terhadap anggota yang terjun ke politik 3) Bagaimana pandangan Masyarakat terhadap Muhammadiyah Daerah Denpasar. Dalam penelitian ini menggunakan metodelogi sejarah adalah sejarah lisan dan sejarah politik. Dan teori yang digunakan adalah teori ekplanasi, teori interaksionalisme simbolik dan teori multikultur. Hasil penelitian ini adalah aktivitas Muhammadiyah Di denpasar dalam agama dan politik. Dalam penelitian ini menemukan hasil tentang Muhammadiyah di Denpasar saat ini bukan hanya bergerak dibidang agama tetapi juga berpartisipasi dalam politik.
\end{abstract}

Kata kunci: dinamika, politik, Muhammadiyah

\section{PENDAHULUAN}

Salah satu ciri dari pergerakan Indonesia adalah terbentuknya organisasi-organisasi modern yang memiliki bentuk-bentuk kegiatan seperti politik, sosial, maupun keagamaan. Dalam perkembangannya dijumpai organisasi yang awalnya bergeraka dalam bidang sosial kemudian merambah ke kegiatan politik. Salah satu organisasi yang bersifat pembaharuan (tajdid) yaitu Muhammadiyah, sering disebut sebagai gerakan pembaharuan sosio-religius. (Sholihul, 2016:8-9)

Dalam penelitian ini yang menjadi objek penelitian adalah Muhammadiyah yang Berada di Denpasar, provinsi Bali. Kota Denpasar merupakan pusat pemerintahan provinsi Bali yang mana terdapat berbagai ragam budaya maupun bermacam agama yang ada di Indonesia. salah satunya yaitu Islam. Agama Islam adalah agama dengan pemeluk terbanyak

\begin{tabular}{lll}
\hline Info Article & & \\
\hline Received & $:$ & $5^{\text {th }}$ December 2019 \\
Accepted & $:$ & $21^{\text {th }}$ August 2020 \\
Publised & $:$ & $31^{\text {st }}$ August 2020
\end{tabular}


di Bali setelah agama Hindu. (Syamsudduha Saleh, 2013: 167-168)

Muhammadiyah di Denpasar berdiri pada tanggal 27 Februari 1953, perjuangan yang khas yang dilakukan Muhammadiyah di Denpasar adalah pendidikan, walaupun menonjol di bidang pendidikan namun dibidang lainnya seperti sosial dan keagamaan juga menjadi perhatian. (Isria Rizqona, 2017: 2). Dalam pembaharuan di bidang pendidikan inilah Muhammadiyah di Denpasar berhasil mencetak manusia muslim yang berbudi luhur, alim, luas pengetahuannya, dan paham masalah dunia dan agama. Muhammadiyah yang pada awalnya fokus terhadap bidang sosial keagamaan. Namun. Pada tahun 1998 Muhammadiyah terus berkiprah dengan kerja kemasyarakatan untuk memajukan kehidupan bangsa, disertai sikap hikmah dalam menghadapi situasi politik nasional. (Muh Syamsudin, 2017).

Kepekaan terhadap sosial politik ditandai dengan banyaknya kader Muhammadiyah di Denpasar yang terjun ke partai politik baik itu partai PKS, PAN, Demokrat dan partai politik lainnya. Menurut Dealiar Noer, sejak Muhammadiyah lahir pada 18 November 1912, Muhammadiyah bukan hanya sekedar ada, namun terus melihatkan perkembangan yang dinamis. (Dealiar, 1990: 84).

Berdasarkan latar belakang tersebut di atas, penelitian ini berjudul "Dinamika Organisasi Muhammadiyah di Denpasar Dalam Perspektif Sejarah 1998-2018". permasalahan yang dapat dirumuskan sebagai berikut. 1) Bagaimana aktifitas Muhammadiyah Daerah Denpasar dalam ideologi agama? 2) bagaimana pandangan Muhammadiyah Daerah Denpasar terhadap kader yang terjun ke politik? 3) bagaimana pandangan masyarakat lokal terhadap Muhammadiyah Daerah Denpasar?.

\section{METODE}

Metodologi sejarah adalah ilmu yang membicarakan bagaimana cara atau yang harus dilakukan dalam penelitian sejarah. Metodologi sejarah membicarakan persoalan teori, konsep dan sumber-sumber sejarah. Teori dalam dan konsep merupakan alat-alat teoritis dan konseptual yang dipergunakan sebagai alat analisa. (Kuntowijoyo, 2003).

Metodologi sejarah yang akan digunakan dalam penelitian ini adalah sejarah lisan dan sejarah politik. Maka yang akan digunakan adalah model sejarah politik menurut Sartono Kartodirdjo. Melalui metodologi sejarah politik Sartono Kartodirdjo ini, akan dapat diketahui bahwa proses politik sebagai kompleksitas hubungan antara pemimpin dan pengikut, otoritas dan ideologi, ideologi dan mobilisasi, solidaritas dan loyalitas dan lain sebagainya, kesemuanya akan mampu mengungkapkan pola distribusi pengaruh dan kekuasaan (polity) dalam kaitannya dengan society sendiri (pola distribusi hubungan sosial). (Herry Widyastono, 2007).

Untuk metodologi sejarah lisan maka yang digunakan adalah model sejarah lisan Kuntowijoyo, sejarah lisan mempunyai sumbangan yang besar dalam mengembangkan substansi penulisan sejarah. Sejarah lisan memberikan kemungkinan untuk menggali sejarah dan pelaku-pelakunya. Sejarah lisan memungkinkan perluasan permasalahan sejarah, karena sejarah tidak lagi dibatasi dengan adanya dokumen tertulis.

\section{KERANGKA TEORI}

Kajian pustaka Untuk mendukung penelitian ini digunakan beberapa literatur yang dapat dijadikan sebagia acuan pokok sebagai berikut: 1) buku yang berjudul sejarah Muhammadiyah Denpasar tahun 1953-1965 yang ditulis 
oleh Faqih Hasan. 2) buku Karya DR. Haedar Nashir yang berjudul "Manhaj Gerakan Muhammadiyah: Ideologi, Khittah, dan Langkah". 3) skripsi karya I Ketut Ardhana yang berjudul "Perkembangan Muhammadiyah di Bali (1934-1968)”. 4) skripsi karya Zainul Mukhsen yang berjudul "Dinamika Jamaah Ahmadiyah Indonesia (JAI) di Bali 1953-2015"

Kerangka teori dalam pendekatan ilmu sejarah dipergunakan untuk menjelaskan bagaimana suatu penelitian terjadi dan menjawab pertanyaanpertanyaan penelitian yang bersifat introgatif yaitu : apa yang terjadi, kapan terjadinya, dimana kejadiannya dan siapa yang berperan. Sedangkan untuk menjawab pertanyaan yang bersifat analisis yaitu mengapa suatu peristiwa itu terjadi maka diperlukan bantuan konsepkonsep ilmu sosial untuk membantu menerangkan, menganalisis berbagai unsur dan berbagai faktor penyebab.

Ida Bagus Sidemen menyebutkan lima unsur teori sejarah, yakni pemahaman dalam sejarah (Historical understanding), penjelasan masa lalu (Historical explanation), objektivitas dalam sejarah (Historical Objectivity), kausalitas dalam sejarah (Historical causation), dan determinasi dalam sejarah (Historical determinisme). Untuk itu, diperlukan teori kritis dan relevan dipakai untuk mencari dan menemukan data serta meganalisisnya dalam sebuah rekontruksi sejarah. Dalam hal ini untuk menjawab permasalahan tersebut akan digunakan teori ekplanasi, Interaksinalisme Simbolik dan teori multikultur.

\section{HASIL DAN PEMBAHASAN}

\section{Sejarah Berdirinya Organisasi Muhammadiyah Di Denpasar}

Sejarah berdirinya Muhammadiyah tidak terlepas dari peran pendiri gerakan ini yaitu Kyai Haji Ahmad Dahlan di
Yogyakarta pada tanggal 18 November 1912. Muhammadiyah adalah Gerakan Islam yang melaksanakan dakwah Amar Makruf Nahi Munkar dengan maksud dan tujuan menegakkan dan menjunjung tinggi agama Islam sehingga terwujud masyarakat Islam yang sebenarbenarnya.(Fattah Santoso, Maryadi, 2000). Muhammadiyah berkeyakinan bahwa Islam adalah agama Allah yang diwahyukan kepada Rasul-Nya, sejak nabi Adam, Nuh, Ibrahim,Musa, Isa dan hingga Nabi penutup Muhammad Saw, sebagai hidayah dan rahmat Allah kepada manusia sepanjang masa.

Muhammadiyah pertama kali di Bali berdiri pada tahun 1934 yaitu di kabupaten Negara dan 1940 di Singaraja yang pada saat itu banyak pegawai negeri dari Jawa yang ditugaskan di Singaraja maka berdirilah persyarikatan Muhammadiyah. Hal ini juga mengimbas ke kota Denpasar. Sekretariat Pimpinan Wilayah Muhammadiyah Bali beralamat di JL. Imam Bonjol NO. 51 Pemecutan Kelod Denpasar Barat.

Kedudukan Sekretariat Pimpinan Daerah Muhammadiyah Kota Denpasar saat ini berada di JL. Pulau Selayar No.19 A, Denpasar. Muhammadiyah daerah Denpasar berdiri pada tanggal 27 Februari tahun 1953 yang diketuai oleh Syaihan, seoarang pegawai Departemen Agama, yang berasal dari kota Makassar. Sebelum berganti nama, Pimpinan Daerah Muhammadiyah Denpasar (PDM Denpasar) dulunya adalah Pimpinan Muhammadiyah Cabang Denpasar, cikal bakal pimpinan Wilayah Muhammadiyah Bali, sebelumnya secara teritori adalah Pimpinan Daerah Muhammadiyah Badung (PDM Badung) atas perkembangannya mulai tahun 1990-an terjadi pemekaran yakni dipisah antara PDM Badung dan PDM Denpasar.

Pada tahun 1953, Muhammadiyah hanya bergerak pada Amal Usaha seperti Pengajian-pengajian keliling dari rumah kerumah, yakni yang diisi oleh ketua 
bagian Tabligh yaitu ustadz Damzuki. Karena syaihan sudah tidak menetap lagi di Bali, kepemimpinan dilanjutkan oleh ustadz Damzuki sampai tahun 1955. Ustadz Damzuki merupakan seorang guru di Madrasah Islamiyah di JL. Hasanuddin, sebelah Masjid Uhuwwah. Periode 1995-1958 Muhammadiyah Denpasar dipimpin oleh M.Shiddiq, pegawai Rohdam Udayana, berasal dari kota Magelang Jawa Timur. (Suwarno, 2008).

Muhammadiyah Denpasar periode tahun 1958-1961 dan 1961-1965 dipimpin oleh Faqih Hasan. Dalam periode ini banyak Pekerjaan dan cobaan yang telah dilalui, seperti salah satunya: Pada 20 April 1964 gedung SD/SMP Muhammadiyah di JL. Imam Bonjol diserbu oleh Golongan ummat Islam yang tidak senang dengan Muhammadiyah. Tidak hanya itu Muhammadiyah Daerah Denpasar juga bersiap-siap mengahadapi G-30-S/PKI. Dan lain-lainya. (Dja'far Siddiq, 2007).

\section{Situasi Politik Kota Denpasar pada Masa Reformasi}

Pada Pemilihan Umum (Pemilu) yang diselenggarakan pada tahun 1955 di Bali khususnya Denpasar, Partai Nasionalis Indonesia (PNI) muncul sebagai partai yang paling mendominasi, selanjutnya Partai Sosialis Indonesia (PSI), lalu Partai Komunis Indonesia (PKI), kemunculan Golongan Karya pada masa Orde Baru secara mencolok mengubah arah politik di Denpasar. Golkar yang hidup selama 32 tahun berhasil membentuk basis sosial yang baru (new basic social). (Farahdiba Rahma Bachtiar, 2014).

Selama 32 tahun masa pemerintahan Soeharto yang dirasa tidak pro rakyat, hal inilah yang menjadi pemicu seluruh mahasiswa melakukan demonstrasi dengan semangat reformasi, dengan tujuan untuk menurunkan secara paksa presiden Soeharto dari jabatannya, situasi yang terjadi dikancah politik ditingkat nasional mempengaruhi situasi politik lokal seperti yang terjadi pada mahasiswa maupun masyarakat Denpasar. Gerakan Reformasi nasional diawali dengan aksiaksi politik jalanan guna menentang hegemoni rezim pada masa Orde Baru, yang pada saat itu juga terjadi oleh masyarakat Denpasar. Gerakan yang dimotori oleh mahasiswa termasuk Lembaga Dakwah Kampus (LDK) bersama rakyat Bali ikut turut serta turun ke jalanan. Tuntutan mereka bagian dari Tuntutan nasional yang telah dikonsolidasikan secara sistematis oleh seluruh komponen gerakan yang pro reformasi sampai ke tingkat daerah. (Acep Iwan Saidi, 2007).

Hampir setiap Pemilu partai Golkar selalu menang pada masa Orde Baru dari tahun 1971 hingga 1997. Tetapi berubah signifikan semenjak runtuhnya rezim Orde Baru. Partai Demokrasi Indonesia Perjuangan (PDI Perjuangan) muncul menjadi partai yang paling dominan. Dari sinilah muncul anggapan bahwa Bali termasuk Denpasar merupakan basis dari PDI Perjuangan.

Periode Reformasi bermula ketika presiden Soeharto turun dari jabatannya pada tanggal 21 Mei 1998. Semenjak itu tekanan dan desakan untuk diadakan pembaharuan kehidupan politik kearah yang lebih Demokratis, dalam hal kepartaian ada tuntutan agar masyarakat mendapatkan kesempatan untuk mendirikan partai. Atas dasar itu pemerintah yang dipimpin oleh BJ Habibie mengeluarkan Undang-Undang No.2/1999 tentang partai politik. Perubahan situasi politik inilah yang kemudian direspon secara cepat oleh berbagai kelompok, termasuk PAN (Partai Amanat Nasional) yang merupakan salah satu partai yang lahir pada era reformasi. Sejarah berdirinya PAN tidak terlepas dari sosok Amien Rais. (Acep Iwan Saidi, 2007). 
Kegiatan proses pembentukan PAN diawali pada tanggal 5-7 Juli 1998, dilaksanakan Tanwir Muhammadiyah di Semarang yang dihadiri oleh seluruh jajaran Pimpinan Pusat Muhammadiyah serta utusan dari tingkat Wilayah (provinsi). Dalam sidang komisi, mayoritas peserta menginginkan agar warga Muhammadiyah membangun partai yang baru. Namun dalam keputusan resmi dinyatakan, bahwa Muhammadiyah tidak akan pernah berubah menjadi parpol, juga tidak akan membidani lahirnya sebuah parpol, tetapi warga Muhammadiyah diberi keleluasaan untuk terlibat dalam parpol sesuai dengan minat dan potensinya.

Sekalipun tak ada hubungan organisasi antara Partai Amanat Nasional (PAN) dan Muhammadiyah, sangat susah untuk memisahkan PAN dan Muhammadiyah "PAN adalah Muhammadiyah, Muhammadiyah adalah PAN". Sehingga notabene PAN adalah orang-orang Muhammadiyah, tetapi tidak semua orang Muhammadiyah adalah PAN.

\section{Struktur Organisasi Muhammadiyah di Denpasar}

Struktur Muhammadiyah Daerah Denpasar sama halnya dengan struktur organisasi di Pusat dan daerah lainnya. Yakni susunan organisasi vertikal dan susunan organisasi horizontal. Susunan organisasi vertical meliputi gerak perluasan muhammadiyah ke seluruh wilayah, daerah, cabang, ranting, mengikuti organisasi pemerintahan. Sedangkan susunan organisasi horizontal merupakan perluasan bidang amal usaha Muhammadiyah. Untuk Muhammadiyah Daerah Denpasar, memiliki 4 cabang yaitu Muhammadiyah cabang Denpasar Selatan, Denpasar Barat, Denpasar Timur, Denpasar Utara.

Salah satu Pimpinan Cabang yang aktif yaitu Pimpinan Cabang Denpasar Barat, pada 19 April 2015 mengadakan kegiatan yang bertempat di SD
Muhammadiyah 3 Denpasar yakni digelarnya acara "Pelatihan Khotib Jum 'at" yang bertujuan mencetak kaderkader yang siap terjuan ke ummat sebagai khotib jum'at di masjid-masjid yang tersebar di Kota Denpasar dan sekitarnya. Pelatihan yang digelar menghadirkan narasumber yaitu Ust Husni Abadi Bin Hazbullah yang merupakan mantan Ketua Pemuda Muhammadiyah Kota Denpasar dan Ust Ridwan Saidi. (Arifin Zain., Maimun Fuadi, 2017).

Selain itu, untuk membangun kekuatan dan solidaritas organisasi PDM Denpasar mengadakan konsolidasi di Pimpinan Cabang Muhammadiyah (PCM) Denpasar Timur, pada 26 Januari 2018. Pembentukan (Elaborasi) kekuatan sebuah keniscayaan untuk kemajuan Muhammadiyah Denpasar beserta cabang Muhammadiyah se Kota Denpasar.

\section{Amal Usaha Muhammadiyah dalam Bidang Agama, Sosial, dan Pendidikan}

Amal usaha pada masa perintisan di Denpasar masih berkisar pada pengajian-pengajian keliling dari rumah kerumah yang diisi oleh Ustadz Damsuki. Hal ini dilakukan untuk mengajarkan hal-hal yang baik dan mengajarkan ajaran Islam sesuai AlQur'an dan Hadist. Hingga saat ini Dakwah masih berjalan, dakwah dilaksanakan melalui pengajian ditempat-tempat pengajian di Denpasar, serta melalui pendidikan. Dan Muhammadiyah Daerah Denpasar juga mengadakan pengajian ibu-ibu Muhammadiyah yang disebut 'Aisyiyah Daerah Denpasar yang berdiri pada tanggal 22 Desember 1963.

Di PDM Denpasar juga sesekali mengadakan pengajian antar penguruspengurus serta jajaran struktur Muhammadiyah Daerah Denpasar, selain untuk membahas masalah agama 
juga guna untuk memperat hubungan silaturrahmi antar pengurus dan jajaran lainnya. Pimpinan Daerah Muhammadiyah Kota Denpasar, melaksanakan Kajian Tarjih di Mushola SD M 1 Denpasar pada 09 November 2018 bersama Ustadz Hamsun Imtihan, sera melaksanakan pengajian rutin bulanan yang seperti pada sabtu, 10 November 2018 dengan tema " Refleksi Nilai Warga dan Pengurus Muhammadiyah", pengajian ini diisi oleh Ustadz H. Sukirman. Pengajian ini dilaksanakan di PDM Denpasar yang dihadiri oleh pengurus dan beberapa warga sekitar (Robby H. Abror, 2012).

Dalam bidang sosial, Muhammadiyah tidak terlepas dari peran 'Aisyiyah Daerah Denpasar yang berdiri tahun 1963 yang diketuai oeh Tut Sunartinah. Untuk periode 2015-2020 ketua Aisyiyah adalah Sutini Eko. Kedudukan 'Aisyiyah dalam organisasi Muhammadiyah adalah sebagai badan pembantu Muhammadiyah yang bertugas mengurus anggota wanita Muhammadiyah. Beberapa kegiatan yang dilakukan oleh bidang sosial selain melakukan aksi sosial juga melakukan berbagai acara sosialisasi seperti pada 22 Januari 2017 juga melaksanakan sosialisasi pencegahan bahaya narkoba yang melibatkan 150 peserta yang terdiri dari guru, tenaga kependidikan dan pihak terkait lainnya di aula SD Muhammadiyah 3 Denpasar. Acara sosialisasi ini menggandeng DPW Gerakan Anti Narkoba Nasional (Gannas) Bali untuk sosialisasi pencegahan bahaya narkoba dengan narasumber Roy Samudra selaku pengurus Gannas Bali.

Pendidikan Muhammadiyah adalah salah satu faktor yang mendasari Muhammadiyah didirikan. Bidang pendidikan adalah Amal Usaha yang paling berkembang diantara amal usaha yang lain di PD Muhammadiyah Kota Denpasar. Terdapat 8 Sekolah yaitu diantaranya 4 SD Muhammadiyah, 2 SMP Muhammadiyah, 2 SMK Muhammadiyah. (Leni Marlina, 2012).

Bagi Muhammadiyah, pendidikan mempunyai arti penting. Oleh karena itu, tidaklah mengherankan jika program nyata yang paling awal dilakukan oleh Muhammadiyah Daerah Denpasar adalah mengembangkan pendidikan. Dibidang ini, paling tidak ada dua segi yang menjadi sasaran pembaruan, yaitu cita-cita dan teknik pengajaran. (Syamsul Arifin, 2015).

\section{Lembaga Amal Zakat, Infaq, Shadaqah Muhammadiyah (LazisMu)}

LazisMu didirikan oleh Pimpinan Pusat Muhammadiyah pada tahun 2002, yang dikukuhkan oleh Menteri Agama Republik Indonesia sebagai Lembaga Amil Zakat Nasional melalui SK No. 457/21 November 2002, dengan telah berlakunya Undang-Undang Zakat nomor 23 tahun 2011, Peraturan Pemerintah nomor 14 tahun 2014, dan keputusan Menteri Agama RI nomor 333 tahun 2015. LazisMu sebagai lembaga amil zakat dikukuhkan kembali melalui SK Menteri Agama RI nomor 730 tahun 2016. (Pimpinan Pusat Muhammadiyah, 2017).

Sehingga pada tahun 2002 didirikan LazisMu Denpasar yang diketuai oleh Subro Mulissyi, yang berada di jl. Pulau Selayar No.21 Denpasar. Salah satu program yang baru-baru ini menyita perhatian warga Muhammadiyah adalah Pada tahun 2018 LazisMu Denpasar melakukan misi kemanusian pada pasca gempa yang terjadi di Lombok. Antusiasme dan Solidaritas masyarakat Bali Khususnya Denpasar membantu korban bencana Lombok terus mengalir, terutama warga Muhammadiyah. 


\section{Dinamika Politik Tokoh Organisasi Muhammadiyah di Denpasar}

a. Pandangan Muhammadiyah Terhadap Kader Yang Terjun Ke Politik.

Politik praktis bukan wilayah Muhammadiyah. Namun, Persyarikatan Muhammadiyah tidak alergi politik. Hal itu tertulis dalam klausul Kepribadian Muhammadiyah 1962. Namun, Muhammadiyah sampai saat ini masih berpegang teguh pada khittahnya sebagai organisasi sosial kemasyarakatan. Sebagaimana dalam Kepribadian Muhammadiyah, organisasi ini bukanlah partai politik, namun bukan berarti Persyarikatan antipolitik dan tidak paham politik.(Suwarno,2005).

Di Muhammadiyah Daerah Denpasar, pada tahun 2000 masa kepemimpinan $\mathrm{H}$. Haris Munandar. Dalam berpolitik Haris Munandar membebaskan para kadernya untuk ikut dalam politik, mereka bebas untuk memilih partai manapun asal tidak melenceng dari aturan atau khittah Muhammadiyah. Husnul Fahmi selaku pimpinan PDM Denpasar periode 20152020 juga membebaskan kadernya untuk terjun ke politik tanpa melencenng dari aturan Muhammadiyah.

\section{b. Peran Pimpinan}

Model kepemimpinan yang merujuk kepada sistem kepemimpinan yang melibatkan pihak yang berkepentingan dalam pengambilan keputusan (kolektif kolegial) setiap Pimpinan Daerah Muhammadiyah Kota Denpasar telah menjadi tradisi dalam tubuh sama seperti Muhammadiyah secara menyeluruh . Hal yang kadang menjadi masalah ialah implementasinya antara ideal dan yang nyata, antara kepentingan individu dan kolektif, antara aktor dan sistem. (Dyah Kumalasari, 2007). Para pimpinan Muhammadiyah Daerah Denpasar juga dituntut untuk memiliki visi misi politik yang luas sebagai basis pengetahuan dan kesadaran dalam menghadapi dinamika yang bersifat kontemporer. Dengan itu, para pimpinan Muhammadiyah dilarang untuk membawa nama persyarikatan Muhammadiyah pada kepentingan politik yang bersifat praktis, karena Muhammadiyah bukanlah organisai sosial keagamaan bukan politik praktis.

\section{c. Pandangan Masyrakat Lokal}

Dalam suatu masyarakat pastilah memiliki persepsi yang berbeda-beda mengenai suatu hal. Demikian pula dengan pandangan masyarakat di Denpasar terhadap Muhammadiyah, dimana masyarakat memiliki persepsi yang berbeda-beda mengenai Muhammadiyah. Hal ini dapat disebabkan berbagai faktor diantaranya faktor pengetahuan, pemahaman, keyakinan dan lain sebagainya. (Muh. Syamsuddin, 2017).

Perbedaan-perbedaan persepsi yang terjadi di masyarakat di daerah Denpasar terjadi karena berbagai faktor seperti: perasaan, sikap dan kepribadian individu, prasangka, keinginan atau harapan, perhatian atau fokus masyarakat, proses belajar, nilai dan kebutuhan juga minat, dan motivasi, latar belakang keluarga, informasi yang diperoleh, pengetahuan dan kebutuhan sekitar, hal-hal baru dan familiar atau ketidak asingan suatu objek. Pada dasarnya proses terbentuknya persepsi ini terjadi dalam diri seseorang, namun persepsi juga dipengaruhi oleh pengalaman, proses belajar, dan pengetahuannya.

\section{SIMPULAN}

Muhammadiyah sering disebut sebagai gerakan pembaharuan sosioreligius. Hal ini cukup beralasan, walaupun Muhammadiyah sendiri tidak merumuskan dirinya sebagai gerakan itu. Muhammadiyah berkembang dengan berbagai Amal Usaha yang dijalankannya, seperti amal usaha di 
bidang agama, bidang sosial, dan bidang pendidikan. Akan tetapi Muhammadiyah di Denpasar terkenal atau yang paling berperan penting dan yang paling berkembang pada bidang pendidikan, berbagai strategi dan usaha dilakukan demi berkembangnya Muhammadiyah di Denpasar. Namun tidak hanya itu pada bidang agama seperti pengajian rutin juga terus dilakukan setiap bulannya. Di bidang sosial bersama LazisMu melakukan berbagai aksi sosial dan sosialisasi yang bekerja sama dnegan pihak luar seperti Gannas (Gerakan Anti Narkoba Nasional) Bali

Muhammadiyah di Denpasar yang awalnya berideologikan agama dan bergerak pada bidang sosial keagamaan. Yang dalam kata lain tidak terlibat dalam politik praktis, pada tahun 1998 ketika runtuhnya rezim Soeharto.Periode Reformasi bermula ketika presiden Soeharto turun dari jabatannya pada tanggal 21 Mei 1998. Semenjak itu tekanan dan desakan untuk diadakan pembaharuan kehidupan politik kearah yang lebih Demokratis, Perubahan situasi politik inilah yang kemudian direspon secara cepat oleh berbagai kelompok, termasuk PAN (Partai Amanat Nasional) yang merupakan salah satu partai yang lahir pada era reformasi. Sejarah berdirinya PAN tidak terlepas dari sosok Amien Rais. Semenjak itulah Muhammadiyah tidak terlepas dari politik praktis

Namun dalam keputusan resmi dinyatakan, bahwa Muhammadiyah tidak akan pernah berubah menjadi parpol, juga tidak akan membidani lahirnya sebuah parpol, tetapi warga Muhammadiyah diberi keleluasaan untuk terlibat dalam parpol sesuai dengan minat dan potensinya.

Oleh karena itu, Muhammadiyah di Denpasar membebaskan Warganya untuk ikut dalam prati politik. Karena disisi lain untuk kepentingan berangsa dan bernegara.

\section{REFERENSI}

Abror, Robby H. (2012), Rethinking Muhammadiyah: Masjid, Teologi Dakawah Dan Tauhid Sosial (Perspektif Filsafat Dakwah). Jurnal Ilmu Dakwah, Vol. 6, No. 19, Januari-Juni 2012.

Arifin, Syamsul. (2015), Rekontruksi AlIslam Kemuhammadiyahan (AIK) Perguruan Tinggi Muhammadiyah Sebagai Praksis Pendidikan Nilai. Jurnal Penelitian Pendidikan Agama Dan Keagamaan. Vol. 13, No. 2, Agustus 2015.

Bachtiar, Farahdiba Rahma.(2014). Pemilu Indonesia: Kiblat Negara Demokrasi Dari Berbagai Refresentasi, Jurnal Politik Profetik, Vol. 3, No. 1, 2014.

Firdausyi, Isria Rizqona. (2017). Perkembangan Persyarikatan dan Amal Usaha Muhammadiyah Cabang Merden Purwanegara Banjarnegara, Jurnal Ilmiah Kependidikan, Vol. X, No. 2, Maret 2017.

Jurdi, Syarifuddin. (2004), Elite Muhammadiyah Dan Kekuasaan Politik: Studi Tentang Tingkah Laku Politik Elite Lokal Muhammadiyah Sesudah Orde Baru. Yogyakarta: Gadjah Mada University Press.

Kumalasari, Dyah. (2017). Pendidikan Karakter Dalam Perspektif Tokoh Muhammadiyah. Jurnal Pendidik dan Peneliti Sejarah, Vol. 1, No. 1, Oktober 2017.

Marlina, Leni. (2012). Kajian Terhadap Perkembangan Sekolah Muhammadiyah, TA'DIB, Vol. XVII, No. 01, Juni 2012. 
Muhammadiyah, Pimpinan Pusat. Pedoman Pimpinan Pusat Muhammadiyah tentang Lazizmu. No. 01/PED/I.0/B/2017

Noer, Dealiar (1990). Gerakan Modern Islam di Indonesia 1900-1942, Jakarta: LP3ES.

Saidi, Acep Iwan. (2007). Indonesia Dalam Dua Orde: Sebuah Citra Yang Retak, Jurnal Sosioteknologi, Edisi 10, April 2007.

Saleh, Syamsudduha. (2013). Kerukunan Umat Beragama di Denpasar Bali, $A L-F I K R$, Vol. 17, No. 1, 2013

Santoso, Fattah., Maryadi. (2000), Muhammadiyah Pemberdayaan Umat?. Surakarta: Muhammadiyah University Press.

Siddiq, Dja'far. (2007), Dinamika Organisasi Muhammadiyah di Sumatera Utara, Journal of Contemporery Islam And Muslim Societies, Vol. 1, No.2, JanuariJuni 2007.

Suwarno. (2005), Muhammadiyah di Indonesia: Mata Rantai antara Gerakan Pembaharuan Islam Modern dan Gerakan Wong Cilik, Jurnal Pendidikan Sejarah Historia, Vol. VI, No. 12, 2005.

Suwarno. (2008), Lima Tokoh Pahlawan Dari Muhammadiyah di Indonesia, Jurnal Sosio Humanika, Vol. 1, No. 2, November 2008

Syamsuddin, Muh. (2017), Gerakan Muhammadiyah Dalam Membumikan Wacana Multikulturalisme: Sebuah Landasan Normatif-Institusional. Jurnal Pemberdayaan Masyarakat:
Media Pemikiran dan Dakwah Pembangunan, Vol. 1, No. 2, 2017.

Huda, Sholihul. (2016), Ideologi Muhammadiyah: Varian Ideologi Keberagaman di Muhammadiyah Dari Moderat Hingga Radikal, Islam Kontemporer, Jurnal Studi Keislaman, Vol. 1 No.1, 2016.

Kuntowijoyo. (2003). Metodologi Sejarah Edisi Kedua Yogyakarta: Tiara Wacana.

Widyastono, Herry. (2007), Metodologi Penelitian Ilmiah dan Alamiah, Jurnal Pendidikan dan Kebudayaan, No. 068, September 2007.

Zain, Arifin., Maimun Fuadi. (2017), Internalisasi Nilai-Nilai Modernitas Dalam Gerakan Dakwah Organisasi Muhammadiyah di Aceh, Al-Idarah: Jurnal Manajemen dan Administrasi Islam. Vol. 1, No. 1, Januari-Juni 2017. 